\title{
Cellular oxido-reductive proteins of Chlamydomonas reinhardtii control the biosynthesis of silver nanoparticles
}

\author{
Indu Barwal', Peeyush Ranjan², Suneel Kateriya ${ }^{2}$ and Subhash Chandra Yadav ${ }^{1 *}$
}

\begin{abstract}
Background: Elucidation of molecular mechanism of silver nanoparticles (SNPs) biosynthesis is important to control its size, shape and monodispersity. The evaluation of molecular mechanism of biosynthesis of SNPs is of prime importance for the commercialization and methodology development for controlling the shape and size (uniform distribution) of SNPs. The unicellular algae Chlamydomonas reinhardtii was exploited as a model system to elucidate the role of cellular proteins in SNPs biosynthesis.
\end{abstract}

Results: The C. reinhardtii cell free extract (in vitro) and in vivo cells mediated synthesis of silver nanoparticles reveals SNPs of size range $5 \pm 1$ to $15 \pm 2 \mathrm{~nm}$ and $5 \pm 1$ to $35 \pm 5 \mathrm{~nm}$ respectively. In vivo biosynthesized SNPs were localized in the peripheral cytoplasm and at one side of flagella root, the site of pathway of ATP transport and its synthesis related enzymes. This provides an evidence for the involvement of oxidoreductive proteins in biosynthesis and stabilization of SNPs. Alteration in size distribution and decrease of synthesis rate of SNPs in protein-depleted fractions confirmed the involvement of cellular proteins in SNPs biosynthesis. Spectroscopic and SDS-PAGE analysis indicate the association of various proteins on C. reinhardtii mediated in vivo and in vitro biosynthesized SNPs. We have identified various cellular proteins associated with biosynthesized (in vivo and in vitro) SNPs by using MALDI-MS-MS, like ATP synthase, superoxide dismutase, carbonic anhydrase, ferredoxin-NADP ${ }^{+}$ reductase, histone etc. However, these proteins were not associated on the incubation of pre-synthesized silver nanoparticles in vitro.

Conclusion: Present study provides the indication of involvement of molecular machinery and various cellular proteins in the biosynthesis of silver nanoparticles. In this report, the study is mainly focused towards understanding the role of diverse cellular protein in the synthesis and capping of silver nanoparticles using $C$. reinhardtii as a model system.

\section{Background}

Silver nanoparticles (SNPs) have extensive applications in civil, therapeutic and industrial areas as catalyst, cryogenic superconductor, biosensor, microelectronic and bacteriostatic materials [1-3], etc. These SNPs have been synthesized by various physical, chemical and biological methods. Among the various known synthesis methods, biosynthesis of silver nanoparticles is preferred as it is environmentally safe, low cost and less toxic [4]. These

\footnotetext{
* Correspondence: subhash@ihbt.res.in

'Nanobiology Lab, Biotechnology Division, Council of Scientific and Industrial Research- Institute of Himalayan Bioresource Technology (CSIR-IHBT),

Palampur, H.P. 176061, India

Full list of author information is available at the end of the article
}

biologically synthesized silver nanoparticles (SNPs) could have better applications in therapeutics, drug delivery, anticancer and bio-imaging techniques. It has been known for the long time that in nature a variety of nanomaterials were synthesized by biological machinery. For example, the magneto-tactic bacteria synthesize intracellular magnetite nanocrystallites [5], diatoms synthesize siliceous materials [6], S-layer bacteria produce gypsum/calcium carbonate layers [7] and plants (algae, fungi, gymnosperms and angiosperms) for gold and silver nanoparticles [8]. In the past few years, bioproduction of size and shape controlled SNPs has become a new and interesting research focus of the field [9-11]. The size and shape control of biosynthesized

\section{Biomed Central}


SNPs could be achieved by appreciative workout of biomolecular and biochemical mechanism of SNPs biosynthesis. However, the biosynthesis mechanism of these silver nanoparticles by bio-molecular reduction and stabilization are still elusive. Some reports have highlighted the mechanism of metallic nanoparticles biosynthesis from different biological extract in vitro[12-14]. The overall biosynthesis of silver nanoparticles is reported as two-step reaction [8]. The first step involves trapping of $\mathrm{Ag}^{+}$inside the cell cytoplasm. In the second step, enzymes present in the cells are responsible for the reduction of silver ions. However, these investigators had not delineated the molecular machinery and involvement of biomolecules for SNPs biosynthesis. In another report, the presence of hydrogenase in the $F$. oxysporum broth was assumed to be responsible for the biosynthesis of SNPs [15-17]. This extra cellular enzyme shows excellent redox properties and it can act as an electron shuttle in metal reduction $[15,18]$. It was evident that electron shuttles or other reducing agents (e. g., hydroquinones) released by microorganisms are capable of reducing ions to nanoparticles [19]. However, the possible involvements of various macromolecules for the reduction of silver ion into silver nanoparticles are not reported yet. The identification of macromolecules responsible for the SNPs biosynthesis would delineate the possible mechanism of SNPs production in biological model systems.

Here we report, for the first time, the involvement of various proteins of oxido-reductive system and nuclear histone protein of $C$. reinhardtii along with biochemical substantiation in the biosynthesis and capping of SNPs. The silver nanoparticles associated proteins were identified by mass spectrometry and the synthesized silver nanoparticles were characterized by transmission electron microscope (TEM) for their shape and size distribution. The current research report proposes the possible molecular basis of the biosynthesis of SNPs and the involvement of the oxidoreductive machinery in biosynthesis and stabilization of silver nanoparticles using C. reinhardtii as model system.

\section{Results}

\section{Biosynthesis of silver nanoparticles (SNPs)}

In vitro synthesis of SNPs by C. reinhardtii cell free extract was very slow (completed in 13 days) and synthesis kinetics was sigmoidal (Figure 1a). In vivo biosynthesis of SNPs was comparatively much faster than that of in vitro condition (Figure 1b). The biosynthesis was completed within $10 \mathrm{~h}$ of incubation in vivo (Figure $1 \mathrm{~b}$ ). The reduction of $\mathrm{Ag}^{+}$into $\mathrm{Ag}^{0}$ (SNPs) has appeared just after the incubation and half of the SNPs were synthesized within $30 \mathrm{~min}$. The color of the culture solution turned yellowish brown while the control algal culture
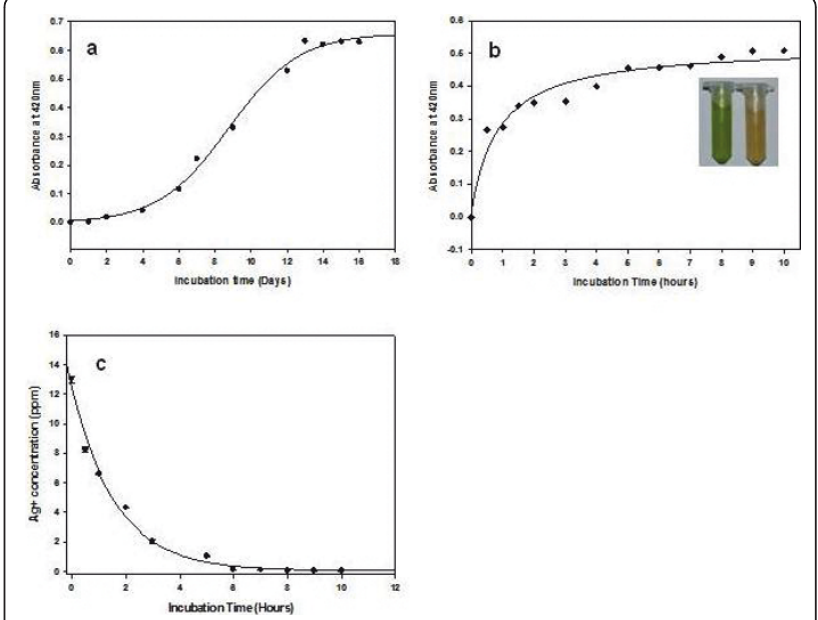

Figure 1 Kinetics of biosynthesis of silver nanoparticles (a) Synthesis of nanoparticles in C. reinhardtii cell free extracts (in vitro) system and (b) in vivo condition. The color of the C. reinhardtii cell becomes yellowish brown after incubation with $1 \mathrm{mM} \mathrm{AgNO}_{3}$ in 5 hours (inset). (c) ICP-MS quantification of remaining $\mathrm{Ag}^{+}$(in ppm) after removal of in vivo biosynthesized SNPs.

(without $\mathrm{AgNO}_{3}$ ) remained green (Figure $1 \mathrm{~b}$ inset). The synthesis of silver nanoparticles by $C$. reinhardtii live cell showed hyperbolic synthesis kinetics (Figure 1b). The maximum level of reduced silver (metal nanoparticles) in C. reinhardtii (in vitro and in vivo) was in the order of $\sim 0.5-0.6$ absorbance unit (Additional File 1). It was found that the amount of SNPs has an upper limit, which depends on the reducing capacity of the biological extracts, $\mathrm{AgNO}_{3}$ concentration and incubation time for the ease of reduction of the metal (Figure 1).

\section{Morphological characterization of biosynthesized SNPs}

Transmission electron microscopy (TEM) was used for morphological characterization of in vitro and in vivo synthesized SNPs. The shape of the biosynthesized SNPs in both conditions were rounded/rectangular. However, the size and universal size distribution were different for in vitro and in vivo biosynthesized SNPs. In vivo biosynthesized SNPs were relatively larger than in vitro biosynthesized silver nanoparticles. The in vitro synthesized nanoparticles were of size range $5 \pm 1$ to $15 \pm 2 \mathrm{~nm}$ (Figure 2a) whereas, the sizes range of in vivo biosynthesized nanoparticles were $5 \pm 1$ to $35 \pm 5 \mathrm{~nm}$ (Figure $2 \mathrm{~b}$ ). The crystalline nature of these nanoparticles was further confirmed by using TEM selected area distribution study (SADS). The bright spot at regular interval confirms the highly crystalline nature of biosynthesized silver nanoparticles (Figure 2a \&2b inset). The EDAX (Energy-dispersive X-ray spectroscopy) analysis also confirms the presence of silver atoms in biosynthesized nanoparticles (Figure 2a \&2b inset). High-resolution (HR) and Fourier transform images are the confirmatory 


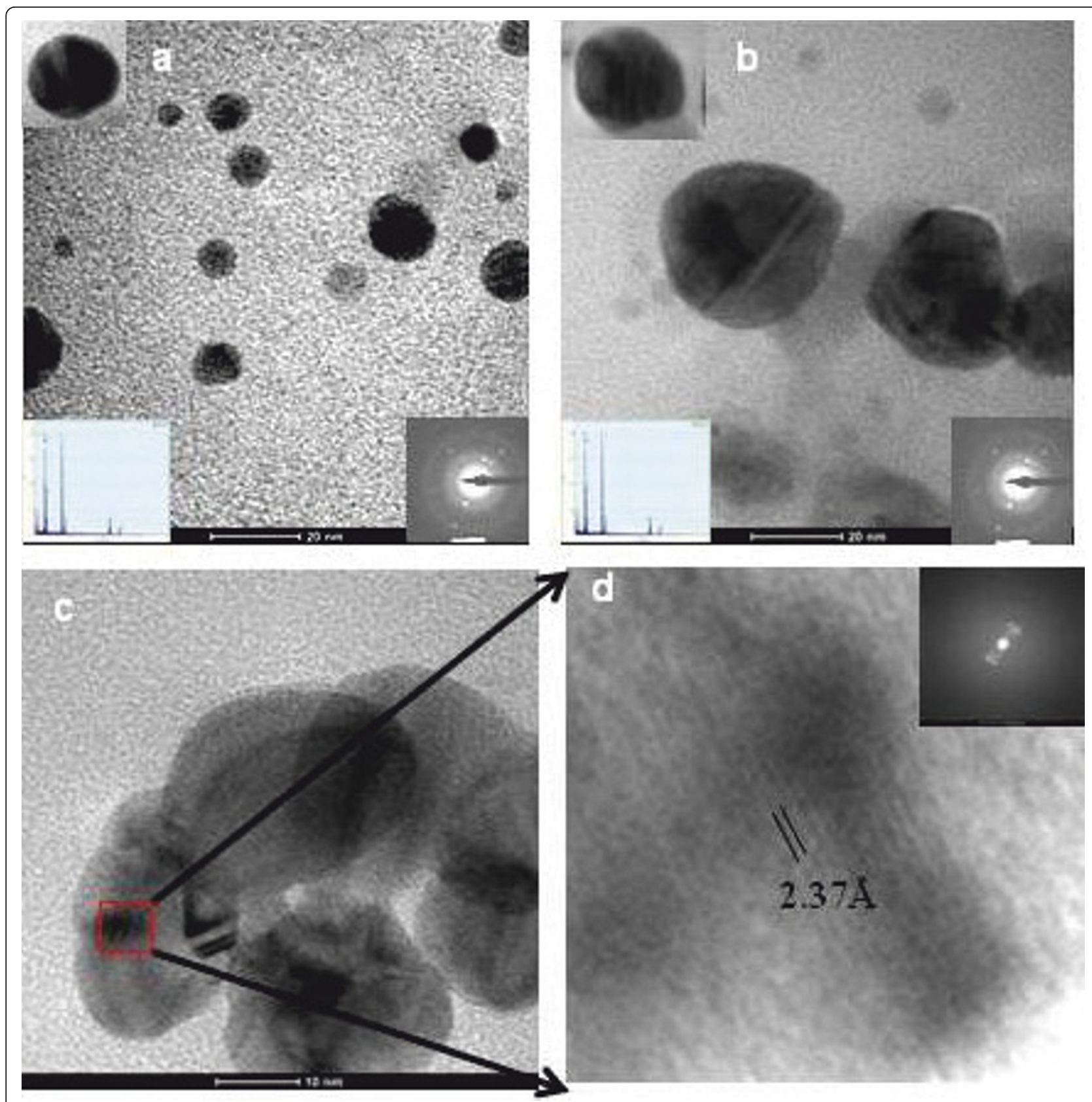

Figure 2 Morphological characterization of the silver nanoparticles. (a) In vitro synthesis, diffraction pattern, and EDAX analysis was given in inset (b) In vivo synthesis and its diffraction pattern (inset) (c) TEM high resolution Image (HR Image) of C. reinhardtii cell mediated synthesized silver nanoparticles and (d) Magnified view of SNPs fringes and Fourier transform image in inset.

signature for crystalline nature of biosynthesized nanoparticles (Figure 2c and 2d).

\section{Localization of in vivo synthesized SNPs in C. reinhardtii cell}

The black regions in the cytoplasm of C. reinhardtii cells were due to the biosynthesis of silver nanoparticles, which were gradually increased and finally filled the complete cell (opaque cell, Figure 3a inset). Similar patterns were also observed by scanning electron microscope (SEM) analysis (Figure 3b). Normal C. reinhardtii cells after incubation with $\mathrm{AgNO}_{3}$ show brighter spot inside the cell due to synthesis of silver nanoparticles (Additional File 2). The SNPs were densely localized in periplasm and cytoplasm in the thin section $(\sim 60 \mathrm{~nm})$ of in vivo biosynthesized SNPs containing cells (Figure $3 \mathrm{a}$ and $3 \mathrm{~b}$ and Additional File 3). On the closer evaluation of the nanoparticles distribution within flagella of 


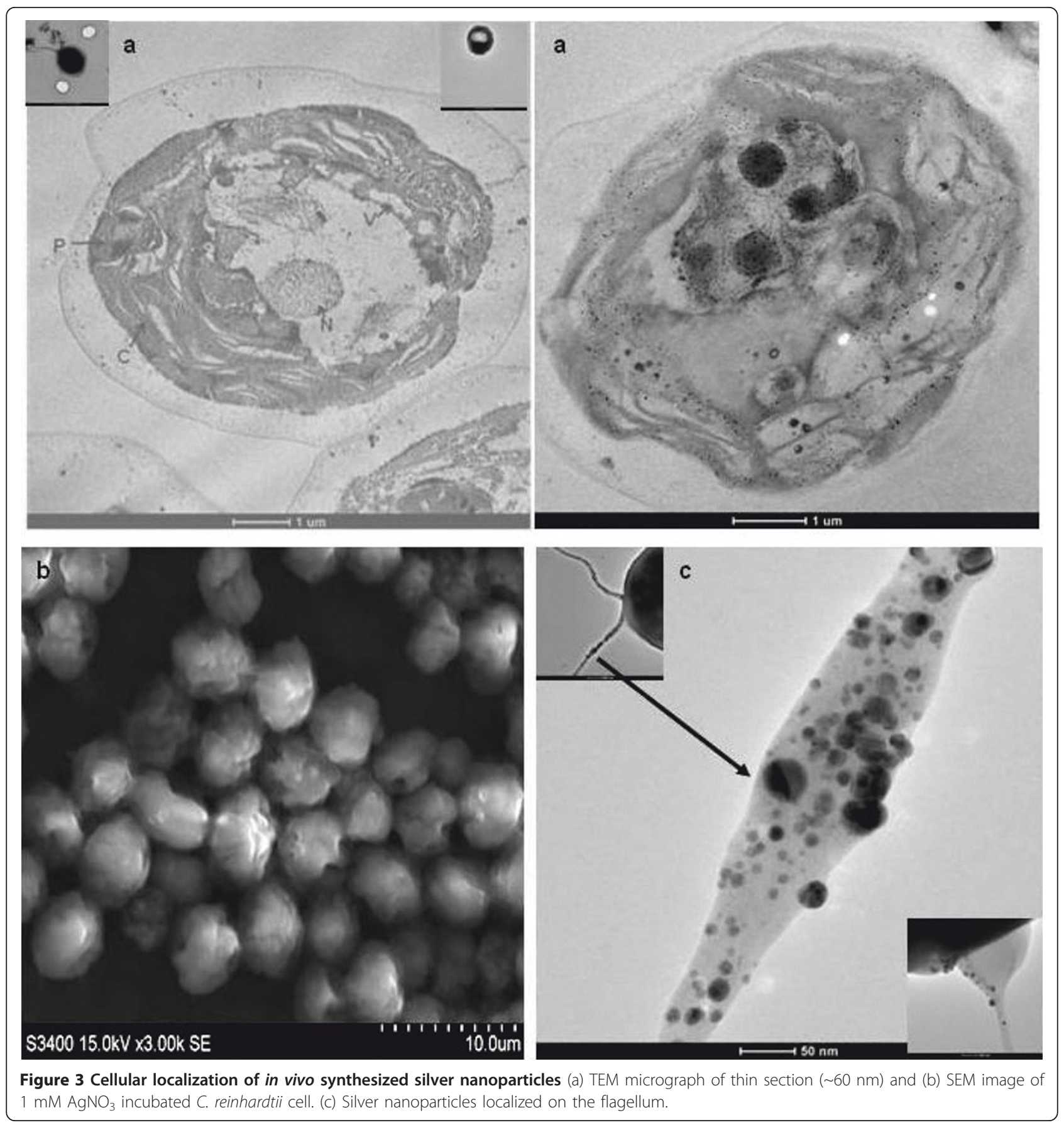

C. reinhardtii cell, it was found that these SNPs were also distributed inside and outside the flagella. The numbers of nanoparticles were more towards the basal body end than the distal end of the flagella (Figure 3c and inset). The SNPs were highly localized at one side of flagella root (basal body) and some part of the flagella was distended due to the presence of excessive amount of nanoparticles internally (Figure 3c and inset).
Protein depletion and its effect on rate of nanoparticles synthesis, morphology and size

Proteins depletion experiments were performed to confirm the role of cellular proteins in the control of synthesis rate of SNPs and their morphology. Cell free extract was depleted on pre-equilibrated anion (DEAE-sepharose) and cation exchange (CM-sepharose) chromatography columns at $\mathrm{pH} 7.0$ to maintain the functional and 
physiological condition of cellular proteins. The SDSPAGE and absorption scan of extract, DEAE and CMsepharose depleted fraction confirmed the various degree of protein depletion (Additional File 4 and 5). The C. reinhardtii cell free extract showed multiple bands, few bands in DEAE-sepharose depleted solution, and no detectable band in CM-sepharose eluted fractions (Additional File 4). The absorption peaks of these eluted fractions were recorded at $280 \mathrm{~nm}$ and their intensity were higher for extract, lower for DEAE-sepharose and lowest for CMsepharose eluted fractions (Additional File 5). The flow through of each column and cell free extract was incubated with $\mathrm{Ag}^{+}$and the synthesis kinetics was measured by absorption spectroscopy. The $C$. reinhardtii cell free extract showed fast synthesis in comparison to that of ion exchange chromatography depleted fractions (Figure $4 \mathrm{a}$ and 4b). CM-sepharose eluted fraction showed lowest synthesis among all the fractions (Figure $4 \mathrm{a}$ and $4 \mathrm{~b}$ ).

The effect of protein depletion on size and morphology was also evaluated by the transmission electron microscope (TEM). The size of nanoparticles synthesized by extract was similar $(5.0 \pm 0.5$ to $\geq 15 \pm 2 \mathrm{~nm})$ as reported (Figure $2 \mathrm{a}$ and $5 \mathrm{a}$ ). However, the size of nanoparticles synthesized by DEAE-sepharose flow through $(20 \pm 4 \mathrm{~nm})$ was larger in comparison to $C$. reinhardtii cell free extract (Figure 5b). CM-sepharose flow through fraction resulted $27 \pm 5 \mathrm{~nm}$ silver nanoparticles synthesis under the similar conditions (Figure 5c).

\section{Identification of SNPs bound proteins}

Proteins associated on the in vitro and in vivo synthesized SNPs were resolved on SDS-PAGE and the protein bands were processed for MALDI-MS and MALDI-MSMS analysis (Figure 6a and 6b). The SNPs associated proteins of in vitro, in vivo, DEAE and CM-sepharose depleted fraction on SDS-PAGE were separately analyzed by MALDI MS-MS de novo sequencing. Nearly 18 silver nanoparticles bound proteins were identified from various biosynthesis conditions. Most of the identified
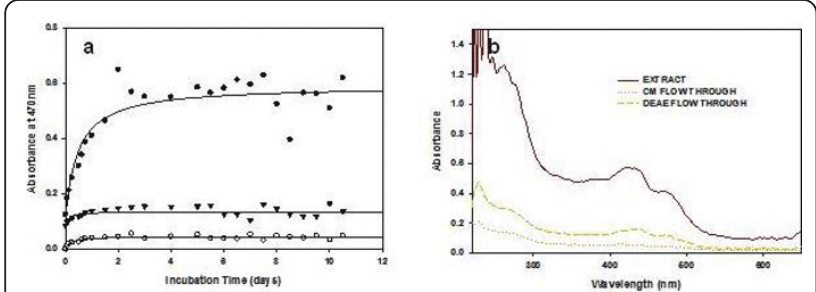

Figure 4 Total protein depletion experiments of $C$. reinhardtii cell free extract (a) Synthesis kinetics of SNPS by $C$. reinhardtii cell free extract $(\bullet)$, DEAE-sepharose $(\mathbf{v})$, CM-sepharose (O) depleted flow through samples (b) The absorbance scans of $C$. reinhardtii cell free extract, DEAE-sepharose and CM-sepharose depleted flow through samples after silver nanoparticles synthesis.

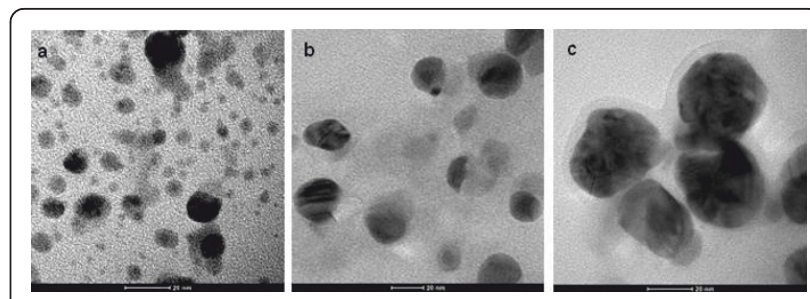

Figure 5 Morphological characterization of protein depleted synthesized SNPs (a) C. reinhardtii cell free extract, (b) DEAEsepharose and (c) CM-sepharose depleted flow through solution synthesized SNPs.

SNPs associated proteins (in vitro and in vivo condition) were the part of oxido-reductive machinery and showed involvement in ATP synthesis, photosystem, and stress response (Additional File 6). The MS-MS and mascot search details of the SNPs associated bound proteins were summarized in the Table 1 . The freshly synthesized and thoroughly washed (to remove proteins and other bound surfactants) silver nanoparticles were incubated with $C$. reinhardtii cell free extracts for 3.0 days at room temperature. Separated and washed pre-synthesized SNPs reveal different protein bands patterns to that of biosynthesized SNPs on SDS-PAGE (Figure 6c).

\section{Discussion}

An important area of research in nanotechnology deals with the controlled synthesis of environmentally benign

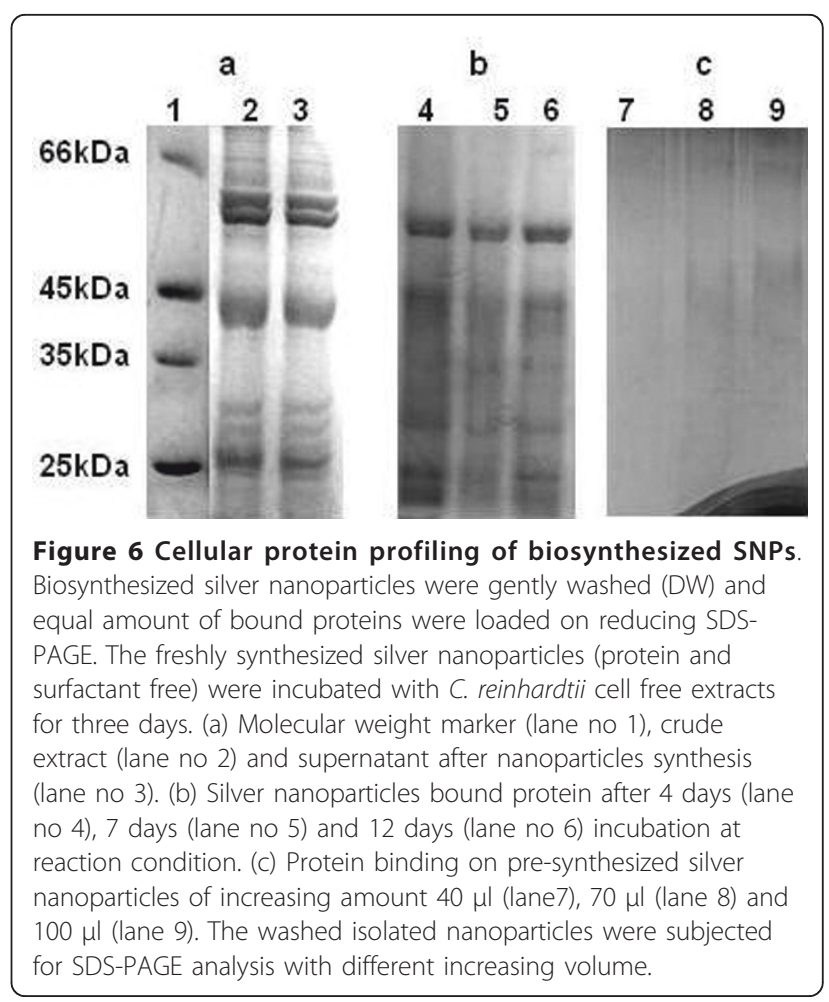


Table 1 MALDI-TOF-TOF of various SNPs associated proteins with matched sequences

\begin{tabular}{|c|c|c|c|c|c|}
\hline No. & Protein Name & MW & $\begin{array}{l}\text { Coverage } \\
(\%)\end{array}$ & Peptide & Full proteins Sequence (Matched peptides bold underlined) \\
\hline 1 & Histone $\mathrm{H} 4$ & 11.4 & 19.4 & $\begin{array}{l}\text { R.ISGLIYEETR.T; K.TFLENVIR.D; R. } \\
\text { DNIQGITKPAIR.R; K.RISGLIYEETR.T }\end{array}$ & $\begin{array}{l}\text { MSGRGKGGKGLGKGGAKRHRKVLRDNIQGITKPAIRRLARRGGV } \\
\text { KRISGLIYEETRTVLKTFLENVIRDSVTYTEHARRKTVTAMDWY } \\
\text { ALKRQGRTLYGFGG }\end{array}$ \\
\hline 2 & Carbonic anhydrase & 41.6 & 42.8 & $\begin{array}{l}\text { K.QSPINVPQYQVLDGK.G; R.IVDV } \\
\text { LEMRPNDAADR.V } \\
\text { R.VTAVPTQFHFHSTSEHLLAGK.I; K. } \\
\text { IYPLELHIVHQVTEK.L; R.EGTFSNL } \\
\text { PAGTTIK.L } \\
\text { K.LGELLPSDR.D; R.ISFGQWNR.Y } \\
\text { K.ATVSGDHWDHGLNGENWEGK.D } \\
\text { R.DYVTYEGSLTTPPCSEGLLW } \\
\text { HVMTQPQR.I }\end{array}$ & $\begin{array}{l}\text { CIYKFGTSPDSKATVSGDHWDHGLNGENWEGKDGAGNAWVCKTGR } \\
\text { KQSPINVPYQVLDGKGSKIANGLQTQWSYPDLMSNGTSVQVINNGHT } \\
\text { IQVQWTYNYAGHATIAIPAMHNQTNRIVDVLEMRPNDAADRVTAVPTQ } \\
\text { FHFHSTSEHLLAGKIYPLELHIVHQVTEKLEACKGGCFSVTGILFQLDNGPDNEL } \\
\text { LEPIFANMPSREGTFSNLPAGTIIKLGELLPSDRDYVTYEGSLTTPPCSEGLLWHV } \\
\text { MTQPQRISFGQWNRYRLAVGLKECNSTETAADAGHHHHHRLLHNHAHLEEVPAAT } \\
\text { SEPKHYFRRVMLAESANPDAYTCKAVAFGQNFRNPQYANGRTIIKLARYH }\end{array}$ \\
\hline 3 & Ferredoxin-NADP reductase & 39.2 & 8.4 & K.VLLLPADANAPLICVATGTGIAPFR.S & $\begin{array}{l}\text { AATKASTAVITDMSKRTVPTKLEEGEMPLNTYSNKAPFKAKVRSVEKITGPKATGETCH } \\
\text { IIIETEGKIPFWEGQSYGVIPPGTKINSKGKEVPTARLYSIASSRYGDDGDGQTASLCV } \\
\text { RRAVYVPETGKEDPAKKGLCSNFLCDATPGTEISMTGPTGKVLLLPADANAPLICV } \\
\text { ATGTGIAPFRSFWRRCFIENVPSYKFTGLFWLFMGVGNSDAKLYDEELQAIAKAYPGQ } \\
\text { FRLDYALSREQNNRKGGKMYIQDKVEEYADEIFDLLDNGAHMYFCGLKGMMP } \\
\text { GIQDMLERVAKEKGLNYEEWVEGLKHKNQWHVEVY }\end{array}$ \\
\hline 4 & Superoxide dismutase & 23.9 & 10.1 & R.RPEYIAAWWNWVNWEQVAENYK.A & $\begin{array}{l}\text { MAQALPPLPYDYGSLEPHVDATTMNIHHTKHHQTYVNNLNAALDKFPELKDLGLV } \\
\text { DLNKAVGTDKLPKDVATVIRNNGGGHYNHSFFWKVMTNPSNTNGPNGDVKAAI } \\
\text { EASFGSVDEMKAKFNAAAAGRFGSGWAWLSVKPDGSLSIDSTPNQDNPLM } \\
\text { TALPDVAGGIPLLGLDVWEHAYYLKYQNRRPEYIAAWWNVVNWEQVAENYKA } \\
\text { AQAGTVPL }\end{array}$ \\
\hline 5 & Sedoheptulose-1,7-bisphosphatase & 41.7 & 21.8 & $\begin{array}{l}\text { R.ATFDNPAYER.L } \\
\text { K.AVSALDIPILVCDQR.T } \\
\text { R.TQICYGSIGEVR.R } \\
\text { R.EQVAAGMGIYGPR.T } \\
\text { R.LINFYLGEK.Y } \\
\text { R.ILFEVAPLALLIEK.A }\end{array}$ & $\begin{array}{l}\text { RAARVQSRRTAVLTQAKIGDSLAEFLVEATPDPKLRHVMMSMAEATRTIAHKVRTASC } \\
\text { AGTACVNSFGDEQLAVDMVADKLLFEALKYSHVCKLACSEEVPEPVDMGGEGFCVV } \\
\text { AFDPLDGSSSSDTNFAVGTIFGWWPGDKLTNITGREQVAAGMGIYGPRTVFCIALKD } \\
\text { APGCHEFLLMDDGKWMHVKETTHIGEGKMFAPGNLRATFDNPAYERLINFYLGEKY } \\
\text { TLRYTGGIVPDLFQIIVKEKGVFTNLTSPTTKAKLRILFEVAPLALLIEKAGGASSCDG } \\
\text { KAVSALDIPILVCDQRTQICYGSIGEVRRFEEYMYGTSPRFSEKWA }\end{array}$ \\
\hline 6 & ATP synthase subunit alpha & 54.7 & 53.5 & $\begin{array}{l}\text { K.MVDFGIVFQVGDGIAR.I; K } \\
\text { IIAEIPVGEAYLGR.V } \\
\text { R.WDGLARPVDGK.G; R.AIESPAPGIVAR.R } \\
\text { R.SVYEPLATGLVAVDAMIPVGR.G } \\
\text { K.TAIAVDTILNQK.G; K.ASSVA } \\
\text { QVLNTLKER.G } \\
\text { R.EAYPGDVFYLHSR.L } \\
\text { K.LKLELAQFAELEAFSQFASDLDQAT } \\
\text { QNQLAR.G } \\
\text { R.STLTFTPEAEGLVK.Q; K.QAINEYL } \\
\text { EEFKSQAK.A } \\
\text { R.TPEELSNLIKDLIEQYTPEVK.M; K.QAQA } \\
\text { YREMSLLLR.R; K.DLIEQ } \\
\text { YTPEVK.M; K.GVICVY } \\
\text { VAIGQK.A; K.QPQSSPLSV } \\
\text { EEQVASLYAGTN } \\
\text { GYLDKLEVSQVR.A }\end{array}$ & $\begin{array}{l}\text { MAMRTPEELSNLIKDLIEQYTPEVKMVDFGIVFQVGDGIARIYGLEKAMSGELL } \\
\text { EFEDGTLGIALNLEANNVGAVLLGDGLKITEGSRVRCTGKIAEIPVGEAYLGR } \\
\text { VVDGLARPVDGKGAVQTKDSRAIESPAPGIVARRSVYYEPLATGLVAV } \\
\text { DAMIPVGRGQRELIIGDRQTGKKTAIAVDTILNQKGKGVICVYVAIGQKASSVA } \\
\text { QVLNTLKERGALDYTIIVMANANEPATLQYLAPYTGATLAEYFMYTGRPTLTIYDDLS } \\
\text { KQAQAYREMSLLLRRPGREAYPGDVFLHSRLLERAKLNNALGEGSM } \\
\text { TALPIVETQEGDVSAYIPTNVISITDGQIFLAAGLFNSGLRPAINVGISVSRVG } \\
\text { SAAQPKAMKQVAGKLKLELAQFAELEAFSQFASDLDQATQNQLARGARLREIL } \\
\text { KQPQSSPLSVEEQVASLYAGTNGYLDKLEVSQVRAYLSGLRSYLANSYP } \\
\text { KYGEILRSTLTFTPEAEGLVKQAINEYLEEFKSQAKAA }\end{array}$ \\
\hline
\end{tabular}


Table 1 MALDI-TOF-TOF of various SNPs associated proteins with matched sequences (Continued)

\begin{tabular}{|c|c|c|c|c|c|}
\hline 7 & ATP synthase subunit beta & 52.0 & 30.9 & $\begin{array}{l}\text { K.GQVPNIYNALTIR.A; R.TAPAFV } \\
\text { DLDTRLSIFETGIK.V } \\
\text { R.LSIFETGIK.V; K.WDLLAPYR.R } \\
\text { K.WDLLAPYRR.G; K.IGLFGGAGVGK.T } \\
\text { K.AHGGVSVFAGVGER.T; K.VALVYGQMNEPPGAR. } \\
\text { M } \\
\text { R.DVNKQDVLFFIDNIFR.F; R.FVQAGAEVSALLGR.M } \\
\text { R.TAPAFVDLDTR.L; R.VALTALTMAEYFR.D } \\
\text { R.DVNKQDVLFFIDNIFR.F; K.TVLIMELINNIAK.A } \\
\text { K.QDVLFFIDNIFR.F }\end{array}$ & $\begin{array}{l}\text { MSDSIETKNMGRIVQIIGPVLDIVFAKGQVPNIYNALTIRAKNSAGTEMAVTCEVQ } \\
\text { QLLGDNCVRAVSMNPTEGLMRGMEVDTGKPLSVPVGKVTLGRIFNVLGEPVDNM } \\
\text { GNVKVEETLPIHRTAPAFVDLDTRLSIFETGIKVVDLLAPYRRGGKIGLFGGAGV } \\
\text { GKTVLIMELINNIAKAHGGVSVFAGVGERTREGNDLYTEMKESGVIVEKNLSDS } \\
\text { KVALVYGQMNEPPGARMRVALTALTMAEYFRDVNKQDVLFIDNIFR } \\
\text { FVQAGAEVSALLGRMPSAVGYQPTLATEMGGLQERITSTKDGSITSIQAVYVA } \\
\text { DDLTDPAPATTFAHLDATIVLSRNLAAKGIYPAVDPLESTSTMLQPWILGEKHYYS } \\
\text { AQSVKKTLQRYKELQDIIAILGLDELEEDRLIVARARKIERFLSQPFFVAEVFTGSPGKY } \\
\text { VSLAETIEGFGKIFAGELDDLPEQAFYLVGNITEAISKAASLK }\end{array}$ \\
\hline 8 & ATP synthase gamma chain & 38.7 & 15.0 & $\begin{array}{l}\text { K.VLYGVNQR.V; R.SLQEALASELAAR.M } \\
\text { R.AQEAWNGRPFSENLVK.V } \\
\text { K.SVLLWLTGDR. }\end{array}$ & $\begin{array}{l}\text { MAAMLASKQGAFMGRSSFAPAPKGVASRGSLQWAGLKEVRDRIASVKNTQKITDA } \\
\text { MKLVAAAKVRRAQEAVVNGRPFSENLVKVLYGVNQRVRQEDVDSPLCAVRPVKSV } \\
\text { LLVVLTGDRGLCGGYNNFIIKKTEARYRELTAMGVKVNLVCVGRKGAQYFARR } \\
\text { KQYNIVKSFSLGAAPSTKEAQGIADEIFASFIAQESDKVELVTKFISLINSNPTIQT } \\
\text { LLPMTPMGELCDVDGKCVDAADDIFKLTTKGGEFAVEREKTIETEALDPSLIF } \\
\text { EQEPAQILDALLPLYMSSCLLRSLQEALASELAARMNAMNNASDNAKELKKG } \\
\text { LTVQYNKQRQAKITQELAEIVGGAAATSG }\end{array}$ \\
\hline 9 & $\begin{array}{l}\text { Oxygen evolving enhancer protein (OEE) } \\
1\end{array}$ & 30.5 & 20.8 & $\begin{array}{l}\text { R.VAFLFTIK.Q } \\
\text { K.VTGLWYAQLK } \\
\text { K.VGSDGSAELKEDD } \\
\text { GIDYAATTVQLPGGER.V }\end{array}$ & $\begin{array}{l}\text { LTFDEIQGLTYLQVKGSGIANTCPVLESGTTNLKELKAGSYKLENFCIEPTSFTVKEESQFKG } \\
\text { GETEFVKTKLMTRLTYTLDAMSGSFKVGSDGSAELKEDDGIDYAATTVQLPGGERVA } \\
\text { FLFTIKQFDGKGTLDGIKGDFLVPSYRGSSFLDPKGRGGSTGYDNAVALPARAD } \\
\text { AEELLKENVKITKALKGSAVFSVAKVDPVTGEIAGVFESIQPSDTDLGAKPPKDIKVTGL } \\
\text { WYAQLK }\end{array}$ \\
\hline 10 & OEE2 & 25.8 & 25.5 & $\begin{array}{l}\text { K.WNPSKENDFPGVILR. } \\
\text { Y; K.ENDFPGVILR.Y } \\
\text { K.QAYSGETQSEGGF } \\
\text { APNR.V; K.TYYKYELLVR.S }\end{array}$ & $\begin{array}{l}\text { AYGDSANVFGKVTNKSGFVPYAGDGFALLLPAKWNPSKENDFPGVILRYEDNFDA } \\
\text { VNNLWIAQDTDKKAIADFGSQDKFLESVSYLLGKQAYSGETQSEGGFAPNRVSAASLL } \\
\text { DVSTTTDKKGKTYYKYELLVRSADGDEGGRHQLIGATVGSDNKLYIIKIQIGDKRWFKG } \\
\text { AKKEAMGAFDSFTW }\end{array}$ \\
\hline 11 & OEE-3 & 21.8 & 25.6 & $\begin{array}{l}\text { K.EFIQAVEDLDFALR.E; R.DRGFDLIYEAR.D } \\
\text { R.GFDLIYEAR.D; } \\
\text { R.DLDLPQNVR.E }\end{array}$ & $\begin{array}{l}\text { LTPVDLFDDRSVRDRGFDLIYEARDLDLPQNVREGFTQARASLDETKKRVK } \\
\text { ESEARIDADLDVFIQKSYWTEAREQLRRQVGTLRFDLNTLASTKEKEAKKAALGLR } \\
\text { KEFIQAVEDLDFALREKDQASAAKKLEITKAKLDSVLAAVL }\end{array}$ \\
\hline 12 & $\begin{array}{l}\text { Ribulose bisphosphate carboxylase } \\
\text { (RuBisCO) (LC) }\end{array}$ & 52.5 & 2.5 & R.FLFVAEAIYK.A & $\begin{array}{l}\text { TKAGAGFKAGVKDYRLTYYTPDYVRDTDILAAFRMTPQLGVPPEECGAAVAAESSTGT } \\
\text { WTIVWTDGLTSLDRYKGRCYDIEPVPGEDNQYIAYVAYPIDLFEEGSVTNMFTSIVGN } \\
\text { VFGFKALRALRLEDLRIPPAYVKTFVGPPHGIQVERDKLNKYGRGLLGCTIKPKLGLSA } \\
\text { KNYGRAVYECLRGGLDFTKDDENVNSQPFMRWRDRFLFVAEAIYKAQAETGEVKG } \\
\text { HYLNATAGTCEEMMKRAVCAKELGVPIIMHDYLTGGFTANTSLAIYCRDNGLLLHIHRA } \\
\text { MHAVIDRQRNHGIHFRVLAKALRMSGGDHLHSGTVGKLEGEREVTLGFVDLMRDD } \\
\text { YVEKDRSRGIYFTQDWCSMPGVMPVASGGIHWWHMPALVEIFGDDACLQFGGGT } \\
\text { LGHPWGNAPGAAANRVALEACTQARNEGRDLAREGGDVIRSACKWSPELAA } \\
\text { ACEVWKEIKFEFDTIDKL }\end{array}$ \\
\hline 13 & RuBisCO (SC) & 20.6 & 39.3 & $\begin{array}{l}\text { K.AYVSNESAIR.F; R.FGSVSCLYYDNR.Y } \\
\text { K.AFPDAYVR.L; K.QVQIMGFLVQRPK.T } \\
\text { R.DFQPANKR.S }\end{array}$ & $\begin{array}{l}\text { MMVWTPVNNKMFETFSYLPPLTDEQIAAQVDYIVANGWIPCLEFAEADKAYVSNESAIR } \\
\text { FGSVSCLYYDNRYWTMWKLPMFGCRDPMQVLREIVACTKAFPDAYVR } \\
\text { LVAFDNQKQVQIMGFLVQRPKTARDFQPANKRSV }\end{array}$ \\
\hline
\end{tabular}


nontoxic nanoparticles of desired shape, sizes and monodispersity. As a result, researchers in the field of nanoparticles synthesis have turned to biological systems to achieve desired qualities in synthesized nanoparticles. Many organisms (both unicellular and multi-cellular) are able to produce nanomaterials either intra- or extracellularly, which are mediated by various oxidoreductive molecules in the cells [16,20-27]. However, the molecular identity and role of these biomolecules in SNPs biosynthesis are yet to be reported. Our experiment shows that $C$. reinhardtii cells (in vivo) mediated biosynthesis of SNPs is faster than that of the in vitro (with cell free extract) condition (Figure 1a and 1b). This is due to the presence of different active biomolecules in the live cells (in vivo) than the cell free extract. In vivo synthesized nanoparticles are localized in cytoplasm, periplasm, nucleus, pyrenoids, and also in the flagella assembly as reported for the $S$. algae $[7,28,29]$ (Figure 3). Incubation of the pre-synthesized silver nanoparticles in vitro does not bind any protein while under similar condition the biosynthesized SNPs does (Figure 6b and 6c). This confirms that these proteins only bind to SNPs during biosynthesis and it does not bind on the pre-synthesized silver nanoparticles surface. These findings indicate that the active proteins in cells play major role in the silver nanoparticles biosynthesis.

Most of the C. reinhardtii cellular protein has been depleted with CM- and DEAE-sepharose ion exchange columns (Additional File 3). The proteins depleted fractions show large size SNPs and slower synthesis (Figure 4). This is an indication of direct involvement of active proteins in SNPs synthesis. It was observed that the size of biosynthesized SNPs is inversely proportional to the total protein content. This might be one of the reasons for the synthesis of large-sized silver nanoparticles in the $\mathrm{CM}$ and DEAE-sepharose depleted protein fractions than cell free extracts (Figure 5). CM-sepharose protein depleted fraction resulted bigger sized nanoparticles than DEAE-sepharose protein depleted fractions (Figure 5). These biosynthesized metallic nanoparticles showed size dependent collective oscillation of the conductance electron at different wavelengths and their crystalline nature (SADS, HRTEM, \& Fourier image) is similar to that of the chemically synthesized SNPs [16,30]. A variety of silver nanoparticles (size and shape) are synthesized due to the amount and reactivity of proteinaceous and non-proteinaceous oxidoreductive species and surfactants present in the biological system [21,26,31] (Figure 2).

Biologically synthesized silver nanoparticles (SNPs) could have many applications in various fields but the uncontrolled synthesis (with respect to size and shape of SNPs) is major drawback for the commercial production of SNPs using the biological system. The evaluation of molecular mechanism of biosynthesis of SNPs is of prime importance to understand biosynthesis process and the development of methodology for controlling the shape and size (uniform distribution) of SNPs. In this report, the study is mainly focused to understand the role of diverse algal cellular proteins in the biosynthesis and capping of silver nanoparticles. Spectroscopic and SDS-PAGE analysis indicate the accumulation of various cellular proteins on C. reinhardtii mediated (in vivo and in vitro) SNPs biosynthesis. Proteins involved in the SNPs biosynthesis were identified by MALDI-MS-MS using mascot platform. Most of these SNPs bound proteins are from oxidoreductive machinery of Chlamydomonas cells. The major SNPs associated proteins are identified as ATPase, sedoheptulose-1,7-bisphosphatase, carbonic anhydrase, ferredoxin $\mathrm{NADP}^{+}$reductase (FNR), superoxide dismutase (SOD), oxygen evolving enhancer protein (OEE), ribulose bisphosphate carboxylase and nuclear histone (H4) (Table 1). Our experimental finding of histone association with biosynthesized SNPs indicates the role of $C$. reinhardtii histone $(\mathrm{H} 4)$ in the SNPs synthesis and capping. Carbonic anhydrase (CA), Ferredoxin and Ferredoxin $\mathrm{NADP}^{+}$reductase (FNR) proteins are also found associated with synthesized SNPs. The histone (H4) is well known for the reduction of silver ammonia complex into $\sim 20 \mathrm{~nm} \mathrm{SNPs}$ and binds SNPs with lysine rich AKRHRK domain [32-34]. This histone mediated SNPs synthesis is due to redox reaction activity of this domain [35]. These proteins might act together as redox centre for converting silver ions into SNPs [36,37]. The involvement of NAD in SNPs synthesis has also been predicted by Ahamad et al. [38]. The binding of superoxide dismutase (SOD) with biosynthesized SNPs suggest the involvement of this protein in the reduction of $\mathrm{Ag}^{+}$to SNPs. Recently, it has been shown that superoxide $\left(\mathrm{O}_{2}{ }^{-}\right)$is not only involved in peroxide formation but is also able to reduce $\mathrm{Ag}^{+}$to $\mathrm{Ag}^{0}$. Further, this step might be sufficient for nucleation step in SNPs synthesis and may modulate rate of formation of SNPs [39]. Another SNPs associated protein viz sedoheptulose-1, 7-bisphosphatase (SBPase) might be involved in the capping of SNPs through its free $-\mathrm{SH}$ group, which is generated by thioredoxin mediated reduction $[40,41]$. Biosynthesized SNPs are mostly localized in cup-shaped chloroplast of C. reinhardtii (Figure 3), a major organ for photosynthetic machinery [42]. This machinery responds first to metal stress by over expressing proteins like ATP synthase, RuBP carboxylase and oxygen evolving enhancer protein (OEE) proteins [43-45]. These enzymes are found associated with $C$. reinhardtii mediated biosynthesized SNPs (Table 1).

Based on the current findings and preliminary evidence about the role of the cellular proteins for the 
biosynthesis of silver nanoparticles, it is accomplished that the SNPs biosynthesis is governed by various cellular proteins present in the system. The other small biomolecules may have potential to act as various oxidation-reduction systems for SNPs biosynthesis either separately or as supplementary to these proteins partners. It would be interesting to delineate the role of identified protein molecule(s) in the control of size and/ or shape of the biosynthesized nanoparticles.

\section{Conclusions}

Most of the eukaryotic organisms are reported to have potential to synthesize silver nanoparticles of different shape/size and synthetic rate depending on their proteinaceous and non- proteinaceous biochemical oxidoreductive species. Our work confirms the SNPs biosynthesis potential of $C$. reinhardtii as unicellular model system. Further study to evaluate the molecular mechanism of SNPs biosynthesis, we have found various cellular proteins viz histone (H4), CA, FNR, SOD, SBPase, ATP synthase, RuBP carboxylase, and OEE associated with biosynthesized SNPs. However, these proteins are not associated with the pre-synthesized silver nanoparticles. The alterations in size and biosynthesis rate of SNPs by proteins depleted fractions confirm that these proteins have direct control on C. reinhardtii mediated biosynthesis of SNPs. This is the first report of elucidation of molecular machinery and the role of oxidoreductive cellular proteins in the biosynthesis of silver nanoparticles.

\section{Methods}

\section{Culture of the C. reinhardtii}

Chlamydomonas strain CC-124 (green algae) was procured from Chlamydomonas centre, Duke University, U. S.A. The culture was maintained on agar plate by adding $1.5 \%$ agar in TAP media supplemented with Hutner's trace element solution. Culture was grown in TAP media under optimum light conditions i.e, 2300 lux. Cells were collected by centrifugation at $3500 \mathrm{rpm}$ for $5.0 \mathrm{~min}$ at room temperature and washed properly with distilled water (DW).

\section{Preparation of C. reinhardtii cell free extract for nanoparticle biosynthesis}

Typically, $2 \mathrm{~g}$ (wet weight) biomass of $C$. reinhardtii was suspended in $20 \mathrm{ml}$ of double distilled sterile water for $2 \mathrm{~h}$ at $27^{\circ} \mathrm{C}$ in an Erlenmeyer flask with gentle agitation followed by vortexing with glass beads. To avoid heating due to the vigorous mixing, the cells were agitated for 1 min, followed by a $30 \mathrm{~s}$ cooling period between agitation cycles. Finally, the cells were broken by intermittent sonication ( 2 second on and 10 second off pulse) at $4^{\circ} \mathrm{C}$ in ice for $10 \mathrm{~min}$ at $40 \%$ amplitude. The cell suspension was examined microscopically until most of the cells were broken. Cell free filtrate was obtained by centrifugation of the C. reinhardtii at $10000 \mathrm{rpm}$ for $10 \mathrm{~min}$ at $4^{\circ} \mathrm{C}$. This solution $(10 \%$ wet $\mathrm{w} / \mathrm{v})$ was used for the further experiments.

\section{Silver nanoparticles synthesis In vitro}

The SNPs synthesis reaction was carried out by incubating $10 \%(v / v)$ of cell free extract with $1.0 \mathrm{mmol} \mathrm{L}^{-1}$ aqueous $\mathrm{AgNO}_{3}$ (double distilled water) solution for 15 days at room temperature in dark. The change in color of the whole solution was an indication of the synthesis of SNPs. The solution was centrifuged at $12000 \mathrm{rpm}$ for 20 min to separate the SNPs. These SNPs were washed five times with double distilled water and separated from reaction mixture along with the associated proteins.

\section{In vivo}

The optimally grown culture $(100 \mathrm{ml})$ was centrifuged (3000 rpm) for $5 \mathrm{~min}$ in sterile condition, washed three times to remove the culture medium and resuspended in $50 \mathrm{ml}$ autoclaved water. The stock solution of $\mathrm{AgNO}_{3}$ (autoclaved) in water was added to make the final $1 \mathrm{mM} \mathrm{AgNO}$ solution. One $\mathrm{ml}$ reaction solution was harvested, sonicated, filtered to remove cell debris, centrifuged, washed and resuspended in $200 \mu \mathrm{l}$ of distilled water at different time intervals (Figure 1) to study the kinetics of SNPs synthesis. The absorbance scan was taken for the entire sample and the biosynthesized SNPs were characterized electron microscopically/elemental/ crystallinity for their morphology using TEM, EDAX and HRTEM image respectively.

\section{Spectroscopic and kinetic characterization of silver nanoparticles}

The reduction of silver ions was monitored by measuring absorbance scan at $250-700 \mathrm{~nm}$ at selected time intervals with UV-VIS spectrophotometer (Nano Drop) (Figure 1). Change in color was observed in the silver nitrate solution incubated with the $C$. reinhardtii cell free extract. The silver nanoparticles dispersed in water were kept at room temperature $\left(37^{\circ} \mathrm{C}\right)$ and the absorption at $470 \mathrm{~nm}$ was measured continuously to determine their stability.

The conversion of $\mathrm{AgNO}_{3}$ into SNPs were determined indirectly on Inductively Coupled Plasma-Mass Spectrometry (ICP-MS) by measuring the remaining $\mathrm{Ag}+$ concentration in supernatant after removal of biosynthesized SNPs (by centrifugation) at various time interval $(0,0.5,1, \ldots 10 \mathrm{~h})$. Briefly, $4 \mathrm{ml}$ of the SNPs free supernatant was dried at $105^{\circ} \mathrm{C}$ for $3 \mathrm{~h}$. After addition of $4 \mathrm{ml}$ of concentrated nitric acid and $0.5 \mathrm{ml}$ of concentrated hydrochloric acid, the samples were digested 
by using a microwave power progressively increasing up to $400 \mathrm{~W}$ for $40 \mathrm{~min}$. After cooling, the solutions were accurately diluted to $50 \mathrm{ml}$ with water. One replicate per digestion method was done for each sample and they were analyzed directly by ICP-MS.

\section{SDS-PAGE gel analysis of SNPs associated proteins}

Thoroughly washed C. reinhardtii cellular proteins associated with SNPs were heated at $95^{\circ} \mathrm{C}$ for 5 min to dissociate the cellular proteins from SNPs. The SNPs were separated from the solution by centrifugation at 14000 $\mathrm{rpm}$. The protein content of this solution was quantified by Bradford assay. $100 \mu \mathrm{g}$ (as determined using the Bradford assay) of the soluble proteins were heated at $95^{\circ} \mathrm{C}$ for 5 min in $4 \% \beta$-mercaptoethanol and 2\% SDS. Proteins associated with the SNPs were resolved on 12\% SDS-PAGE.

\section{Sample preparation for proteomics}

Protocol for sample preparation for proteomics analysis of SNPs associated proteins was adopted from published papers $[46,47]$. Briefly, protein bands on SDS-PAGE were excised, de-stained, washed with water and dehydrated with acetonitrile $(\mathrm{ACN})$. Proteins were reduced with 10 mM DTT (dithiothreitol) solution in trypsin digestion buffer at $60^{\circ} \mathrm{C}$ for $30 \mathrm{~min}$. After cooling at room temperature, gels were dehydrated with $\mathrm{ACN}$. The proteins were alkylated with $50 \mathrm{mM}$ iodoacetamide solution in trypsin digestion buffer in dark as per manufacturer's instruction. After washing with ACN, gel samples were dried in speedvac. Gel pieces were rehydrated with trypsin rehydration solution containing $50 \mathrm{ng}$ of trypsin and incubated at $37^{\circ} \mathrm{C}$ overnight for in gel digestion of protein. Peptides were recovered with Pep-extract buffer (supplied with kit), lyophilized, and reconstituted in $10 \mu \mathrm{l}$ of $50 \% \mathrm{ACN}$ and $0.1 \%$ trifluoroacetic acid (TFA).

\section{MALDI MS-MS analysis of SNPs bound proteins}

MALDI experiments were performed on pre-calibrated ABI 4800 plus MALDI-TOF-TOF analyzer (Applied Biosystem) at department of Biochemistry, Delhi University South Campus, New Delhi, India. Reconstituted peptides were spotted on 384 well LC MALDI stainless steel plate. For MS analysis, spots were illuminated with laser intensity of 3500 and total 1200 spectra were recorded [48,49]. For MS-MS analysis, 25 precursors/ peptides were selected from each spot and depending upon their abundance, each precursor was fragmented in the collision cell. Peptide fragmented with 4300 laser intensity and 2500 shots were accumulated for processing of data [50,51].

The resultant PMF and peptide fragments were searched against swissprot database on MASCOT search engine http://www.matrixscience.com. The search of database was focused for Virdiplantae group containing green algae and land plant genome database. The monoisotopic peptide tolerance was kept at $\pm 100 \mathrm{ppm}$ with MS/MS tolerance of $\pm 0.6 \mathrm{Da}$.

\section{Protein depletion experiment}

The protein depletion experiment was carried out to confirm the role of various proteins in the biosynthesis of silver nanoparticles. The C. reinhardtii cell free extract $(5 \mathrm{ml})$ was passed through pre-equilibrated CMsepharose and DEAE-sepharose ion exchange chromatographic column at $\mathrm{pH}$ 7.0. The flow through of each column was used for the biosynthesis of silver nanoparticles and to characterize their synthesis kinetics. Morphological comparisons of the biosynthesized SNPs were characterized by using TEM.

\section{Protein binding assay}

Protein binding assay was performed to confirm the involvement of various proteins either in the synthesis or capping or both. For this purpose, freshly synthesized SNPs (without any protein capping) were incubated with $C$. reinhardtii cell free extract for three days in standard conditions. These nanoparticles were separated, gently washed and heated with $0.2 \%$ SDS to dissolve all the bound protein on nanoparticles. The supernatant after the SDS treatment was resolved on the SDS PAGE.

\section{Electron microscopic characterization of SNPs SEM imaging}

Biosynthesis of silver nanoparticles in vivo was characterized by scanning electron microscope (S-3400 N, Hitachi, Japan). The $\mathrm{AgNO}_{3}$ incubated $C$. reinhardtii cultures at different time $(0,1,5$, and $8 \mathrm{~h})$ were mounted on an aluminum stub using double sided carbon tape. The completely dried sample was coated with gold by sputter coating unit (E1010 ion sputter Hitachi, Japan) and image was captured on SEM mode at desired magnification.

$T E M$, diffraction and EDAX characterization of nanoparticles The morphology and grain size of the $C$. reinhardtii biosynthesized silver nanoparticles were observed by highresolution transmission electron microscopy using FEI G-20 model operated at $200 \mathrm{kV}$. The crystallinity of the nanoparticles was determined using selected area electron diffraction (SAED) coupled with TEM. Elemental analysis of the nanoparticles was carried out using a scanning transmission electron microscope (STEM) equipped with an energy dispersive X-ray (EDX) spectrometer (EDAX). Briefly, the washed biosynthesized SNPs were directly spread on grid and dried before TEM imaging. However, the cells were fixed with glutaraldehyde, $\mathrm{OsO} 4$ and embedded in resins after serial alcohol dehydration for exploring the cellular localization of in vivo synthesized SNPs. The ultrathin sections $(\sim 60 \mathrm{~nm})$ of the cells were used for the TEM imaging. 


\section{Additional material}

Additional file 1: UV visible scan (a) in vitro and (b) in vivo system SNPs biosynthesis. This file shows the absorbance scan at various time (given along with figure) in vitro and in vivo conditions.

Additional file 2: Cellular localization of in vivo synthesized silver nanoparticles. (a) TEM micrograph SNPs synthesizing cell at different time and (b) SEM image of $1 \mathrm{mM} \mathrm{AgNO}_{3}$ incubated C. reinhardtii cell at different time period (given in the right corner of each image).

Additional file 3: Cellular localization of silver nanoparticles inside the cell. Various TEM micrograph of thin section $(\sim 60 \mathrm{~nm})$ of in vivo biosynthesized SNPs containing cells for better conspicuousness.

Additional file 4: SDS-PAGE of equal volume (50 and $100 \mu \mathrm{l})$ of $C$. reinhardtii depleted proteins. Cell free extract (lane 1-2), DEAESpharose depleted flow through (lane 3-4), DEAE 0.5 M salt wash (lane 56), CM-sepharose depleted flow through (lane 7-8), and CM-sepharose $0.5 \mathrm{M}$ salt wash (lane 9-10)

Additional file 5: Absorbance scans of protein depleted fractions The absorbance scans of C. reinhardtii cell free extract, DEAE-Spharose, $\mathrm{CM}$-sepharose depleted flow through samples before $\mathrm{AgNO}_{3}$ incubation.

Additional file 6: PMF (upper panel) and MS-MS (lower panel) spectra of SNPs associated various identified proteins. (a) ATP synthase subunit alpha, chloroplastic OS = Chlamydomonas reinhardtii (b) ATP synthase subunit beta, chloroplastic (c) Carbonic anhydrase (d) Sedoheptulose-1,7-bisphosphatase (e) Ferredoxin, chloroplastic (f) Oxygen-evolving enhancer protein 1, chloroplastic (g) Oxygen-evolving enhancer protein 2, chloroplastic (h) Oxygen-evolving enhancer protein 3 (i) Histone H4. de novo sequence of the peptides was given along with each MS-MS spectra in red.

\section{Acknowledgements}

We are grateful to Dr. PS Ahuja Director, IHBT for providing necessary facilities for carrying out this work. The IHBT communication number of this article is 2216. Financial assistance from Council of Scientific and Industrial Research (CSIR), Department of Biotechnology (DBT) and Department of Science and Technology (DST), Government of India is truly acknowledged.

\section{Author details}

'Nanobiology Lab, Biotechnology Division, Council of Scientific and Industrial Research- Institute of Himalayan Bioresource Technology (CSIR-IHBT), Palampur, H.P. 176061, India. ${ }^{2}$ Department of Biochemistry, University of Delhi South Campus, New Delhi, 110021, India.

\section{Authors' contributions}

IB did the culturing of C. reinhardtii, biosynthesis kinetics, protein depletion and SDS PAGE analysis and PR did the MALDI-TOF-TOF and protein identification. SK and SC wrote the manuscript and design the various experiments. SC performed the electron microscopic analysis using TEM and SEM. All the authors has read and approved this final manuscript for publication.

\section{Competing interests}

The authors declare that they have no competing interests.

Received: 9 June 2011 Accepted: 7 December 2011 Published: 7 December 2011

\section{References}

1. Durán N, Marcato PD, Conti RD, Alves OL, Costa FTM, Brocchi M: Potential use of silver nanoparticles on pathogenic bacteria, their toxicity and possible mechanisms of action. J Braz Chem Soc 2010, 21:949-959.

2. Marcato PD, Duran N: New aspects of nanopharmaceutical delivery systems. J Nanosci Nanotechnol 2008, 8:2216-2229.

3. Rai M, Yadav A, Gade A: Silver nanoparticles as a new generation of antimicrobials. Biotechnol Adv 2009, 27:76-83.
4. Buzea C, Pacheco II, Robbie K: Nanomaterials and nanoparticles: sources and toxicity. Biointerphases 2007, 2:MR17-71.

5. Blakemore RP: Magnetotactic bacteria. Annu Rev Microbiol 1982, 36:217-238.

6. Kroger N, Deutzmann R, Sumper M: Polycationic peptides from diatom biosilica that direct silica nanosphere formation. Science 1999, 286:1129-1132.

7. Konishi Y, Ohno K, Saitoh N, Nomura T, Nagamine S, Hishida H, Takahashi Y, Uruga T: Bioreductive deposition of platinum nanoparticles on the bacterium Shewanella algae. J Biotechnol 2007, 128:648-653.

8. Mukherjee P, Ahmad A, Mandal D, Senapati S, Sainkar SR, Khan MI, Ramani R, Parischa R, Ajayakumar PV, Alam M, et al: Bioreduction of AuCl (4)(-) lons by the Fungus, Verticillium sp. and Surface Trapping of the Gold Nanoparticles Formed. Angew Chem Int Ed Engl 2001, 40:3585-3588.

9. Duran N, Marcato PD, Duran M, Yadav A, Gade A, Rai M: Mechanistic aspects in the biogenic synthesis of extracellular metal nanoparticles by peptides, bacteria, fungi, and plants. Appl Microbiol Biotechnol 2011, 90:1609-1624.

10. Gade A, Ingle A, Whiteley C, Rai M: Mycogenic metal nanoparticles: progress and applications. Biotechnol Lett 2010, 32:593-600.

11. Vaidyanathan R, Kalishwaralal K, Gopalram S, Gurunathan S: Nanosilver the burgeoning therapeutic molecule and its green synthesis. Biotechnol Adv 2009, 27:924-937.

12. Haverkamp RG, Marshall AT: The mechanism of metal nanoparticle formation in plants:limits on accumulation. J Nanopart Res 2009, 11:1453-1463.

13. Harris AT, Bali R: On the formation and extent of uptake of silver nanoparticles by live plants. J Nanopart Res 2008, 10:691-695.

14. Gardea-Torresdey JL, Gomez E, Peralta-Videa JR, Parsons JG, Troiani H, JoseYacaman M: Alfalfa sprouts: a natural source for the synthesis of silver nanoparticles. Langmuir 2003, 19:1357-1361.

15. Duran N, Marcato PD, Alves OL, Souza Gl, Esposito E: Mechanistic aspects of biosynthesis of silver nanoparticles by several Fusarium oxysporum strains. J Nanobiotechnology 2005, 3:8.

16. Ahmad A, Mukherjee P, Senapati S, Mandal D, Khan MI, Kumar R, Sastry M: Extracellular biosynthesis of silver nanoparticles using the fungus Fusarium oxysporum. Colloid surf B: Biointerface 2003, 28:313-318.

17. Ingle A, Gade A, Pierrat S, Sonnichsen C, Rai M: Mycosynthesis of silver nanoparticles using the fungus Fusarium acuminatum and its activity against some human pathogenic bacteria. Current Nanoscience 2008, 4:141-144

18. Gade AK, Bonde P, Ingle AP, Marcato PD, Durán N, Rai MK: Exploitation of Aspergillus niger for synthesis of silver nanoparticles. Journal of Biobased Materials and Bioenergy 2008, 2:243-247.

19. Baker $R$, Tatum J: Novel anthraquinones from stationary cultures of Fusarium oxysporum. J Ferment Bioeng 1998, 85:359-361.

20. Klaus T, Joerger R, Olsson E, Granqvist CG: Silver-based crystalline nanoparticles, microbially fabricated. Proc Natl Acad Sci USA 1999, 96:13611-13614.

21. Li S, Shen Y, Xie A, Yu X, Qiu L, Zhang L, Zhang Q: Green synthesis of silver nanoparticles using Capsicum annuum L. extract. Green Chem 2007, 9:852-858

22. Mandal D, Bolander ME, Mukhopadhyay D, Sarkar G, Mukherjee P: The use of microorganisms for the formation of metal nanoparticles and their application. Appl Microbiol Biotechnol 2006, 69:485-492.

23. Raveendran P, Fu J, Wallen SL: Completely "green" synthesis and stabilization of metal nanoparticles. J Am Chem Soc 2003, 125:13940-13941.

24. Shankar SS, Ahmad A, Sastry M: Geranium leaf assisted biosynthesis of silver nanoparticles. Biotechnol Prog 2003, 19:1627-1631.

25. Shankar SS, Rai A, Ahmad A, Sastry M: Rapid synthesis of $A u, A g$, and bimetallic Au core-Ag shell nanoparticles using Neem (Azadirachta indica) leaf broth. J Colloid Interface Sci 2004, 275:496-502.

26. Song JY, Kim BS: Rapid biological synthesis of silver nanoparticles using plant leaf extracts. Bioprocess Biosyst Eng 2009, 32:79-84.

27. Zhu C, Xue J, He J: Controlled in-situ synthesis of silver nanoparticles in natural cellulose fibers toward highly efficient antimicrobial materials. $J$ Nanosci Nanotechnol 2009, 9:3067-3074.

28. Konishi Y, Tsukiyama T, Ohno K, Saitoh N, Nomura T, Nagamine S: Intracellular recovery of gold by microbial reduction of AuCl4-ions 
using the anaerobic bacterium Shewanella algae. Hydrometallurgy 2006, 81:24-29.

29. Konishi Y, Tsukiyama T, Saitoh N, Nomura T, Nagamine S, Takahashi Y, Uruga T: Direct determination of oxidation state of gold deposits in metal-reducing bacterium Shewanella algae using $\mathrm{X}$-ray absorption near-edge structure spectroscopy (XANES). J Biosci Bioeng 2007, 103:568-571.

30. Mock JJ, Barbic M, Smith DR, DA S, S S: Shape effect in plasmon resonance of indivisual colloidal silver nanoparticles. J Chem Phys 2002, 116:6755-6759.

31. Nune SK, Chanda N, Shukla R, Katti K, Kulkarni RR, Thilakavathi S, Mekapothula S, Kannan R, Katti KV: Green Nanotechnology from Tea: Phytochemicals in Tea as Building Blocks for Production of Biocompatible Gold Nanoparticles. J Mater Chem 2009, 19:2912-2920

32. Black MM, Ansley HR: Histone specificity revealed by ammoniacal silver staining. J Histochem Cytochem 1966, 14:177-181.

33. Kurosaki T, Tsutsui K, Tsutsui K, Aoyama K, Oda T: Mechanism of silver staining of histones: evidence for involvement of clustered lysine residues. Biochem Biophys Res Commun 1984, 123:729-734.

34. Zoroddu MA, Kowalik-Jankowska T, Kozlowski H, Molinari H, Salnikow K, Broday L, Costa M: Interaction of $\mathrm{Ni}(\mathrm{II})$ and $\mathrm{Cu}(\mathrm{II})$ with a metal binding sequence of histone H4: AKRHRK, a model of the H4 tail. Biochim Biophys Acta 2000, 1475:163-168.

35. Midorikawa K, Murata M, Kawanishi S: Histone peptide AKRHRK enhances $\mathrm{H}(2) \mathrm{O}(2)$-induced DNA damage and alters its site specificity. Biochem Biophys Res Commun 2005, 333:1073-1077.

36. Cassan N, Lagoutte B, Setif P: Ferredoxin-NADP+ reductase. Kinetics of electron transfer, transient intermediates, and catalytic activities studied by flash-absorption spectroscopy with isolated photosystem I and ferredoxin. J Biol Chem 2005, 280:25960-25972.

37. Kurisu G, Kusunoki M, Katoh E, Yamazaki T, Teshima K, Onda Y, KimataAriga $Y$, Hase T: Structure of the electron transfer complex between ferredoxin and ferredoxin-NADP(+) reductase. Nat Struct Biol 2001, 8:117-121.

38. Ahmad N, Sharma S, Singh VN, Shamsi SF, AnjumFatma R, Mehta B: Biosynthesis of Silver Nanoparticles from Desmodium triflorum:A Novel Approach TowardsWeed Utilization. Biotechnology Research International 2011, 1-8.

39. Jones AM, Garg S, He D, Pham AN, Waite TD: Superoxide-Mediated Formation and Charging of Silver Nanoparticles. Environ Sci Technol 2011, 45:1428-1434.

40. Hahn D, Kaltenbach C, Kuck U: The Calvin cycle enzyme sedoheptulose1,7-bisphosphatase is encoded by a light-regulated gene in Chlamydomonas reinhardtii. Plant Mol Biol 1998, 36:929-934.

41. Buchanan BB: Role of Light in the Regulation of Chloroplast Enzymes. Annual Review of Plant Physiology 1980, 31:341-374.

42. Pinto E, Sigaud-kutner TCS, Leitão MAS, Okamoto OK, Morse D, Colepicolo P: Heavy metal-induced oxidative stress in algae. Journal of Phycology 2003, 39:1008-1018.

43. Cid C, Garcia-Descalzo L, Casado-Lafuente V, Amils R, Aguilera A: Proteomic analysis of the response of an acidophilic strain of Chlamydomonas sp. (Chlorophyta) to natural metal-rich water. Proteomics 2010, 10:2026-2036.

44. Mayfield SP, Bennoun P, Rochaix JD: Expression of the nuclear encoded OEE1 protein is required for oxygen evolution and stability of photosystem II particles in Chlamydomonas reinhardtii. Embo J 1987, 6:313-318

45. Heide $H$, Kalisz HM, Follmann $H$ : The oxygen evolving enhancer protein 1 (OEE) of photosystem II in green algae exhibits thioredoxin activity. J Plant Physiol 2004, 161:139-149.

46. Cedervall T, Lynch I, Lindman S, Berggard T, Thulin E, Nilsson H, Dawson KA, Linse S: Understanding the nanoparticle-protein corona using methods to quantify exchange rates and affinities of proteins for nanoparticles. Proc Natl Acad Sci USA 2007, 104:2050-2055.

47. Rocker C, Potzl M, Zhang F, Parak WJ, Nienhaus GU: A quantitative fluorescence study of protein monolayer formation on colloidal nanoparticles. Nat Nanotechnol 2009, 4:577-580.

48. Hillenkamp F, Karas M, Beavis RC, Chait BT: Matrix-assisted laser desorption/ionization mass spectrometry of biopolymers. Anal Chem 1991, 63:1193A-1203A.
49. Karas M, Gluckmann M, Schafer J: Ionization in matrix-assisted laser desorption/ionization: singly charged molecular ions are the lucky survivors. J Mass Spectrom 2000, 35:1-12.

50. Kratzer R, Eckerskorn C, Karas M, Lottspeich F: Suppression effects in enzymatic peptide ladder sequencing using ultraviolet - matrix assisted laser desorption/ionization - mass spectormetry. Electrophoresis 1998, 19:1910-1919.

51. Krause $E$, Wenschuh $H$, Jungblut PR: The dominance of argininecontaining peptides in MALDI-derived tryptic mass fingerprints of proteins. Anal Chem 1999, 71:4160-4165.

doi:10.1186/1477-3155-9-56

Cite this article as: Barwal et al: Cellular oxido-reductive proteins of Chlamydomonas reinhardtii control the biosynthesis of silver nanoparticles. Journal of Nanobiotechnology 2011 9:56.

\section{Submit your next manuscript to BioMed Central and take full advantage of:}

- Convenient online submission

- Thorough peer review

- No space constraints or color figure charges

- Immediate publication on acceptance

- Inclusion in PubMed, CAS, Scopus and Google Scholar

- Research which is freely available for redistribution

Submit your manuscript at www.biomedcentral.com/submit 